\title{
The Application of 'Tea Party' Cooperative Learning Model in Nichijo Hyogen Online Course
}

\author{
Rosi Rosiah ${ }^{1, *}$, Arsyl Elensyah Rhema Machawan ${ }^{2}$, Asy Syifa U’Maulida ${ }^{3}$ \\ ${ }^{1,3}$ Department of Japanese Language Education, Faculty of Language Education, Universitas Muhammadiyah Yogyakarta, \\ Indonesia \\ ${ }^{2}$ Department of Japanese Language Education, Faculty of Language Education, Universitas Muhammadiyah Yogyakarta, \\ Indonesia \\ *Corresponding author. Email: rosi.rosiah@umy.ac.id
}

\begin{abstract}
The tea party type of cooperative learning model aims to stimulate the activities of students in learning. This study aims to describe the application of the 'tea party' cooperative learning model in the Nichijo Hyougen course and to find out students' responses to it. The subjects in this study were 48 students. The data obtained from the study are the results of observations, questionnaires, and interviews. Based on the results, the learning flow in applying the 'tea party' cooperative learning model is divided into three stages: introduction, core activity, evaluation, and closing. After the model was applied, students felt they could foster competition in learning, as indicated by $86 \%$ in the result, and $87 \%$ of students agreed that learning with the 'tea party' learning model could help improve learning abilities combined with blended learning.
\end{abstract}

Keywords: Cooperative Learning, Tea Party Type, Japanese Language Daily Expression Online Course

\section{INTRODUCTION}

Roy Kellen, cited in Rusman (2016:132), noted two approaches to learning: teacher-centered and student-centered learning. Educators deliver teacher-centered learning or direct learning as all sources of information. Most students lack interaction in the classroom because all are centered on teachers. While in student-centered learning, the teaching staff is more of a facilitator and a controller in the class so that the material discussed in class continues to be conducive and does not deviate from the plan.

Learning can be done with various learning models. The learning model is a plan or pattern that can form a curriculum (long-term learning plan), design learning materials, and guide learning in the classroom or otherwise (Rusman, 2016:144-145). The pattern of learning models has a lot and has a way of approach. These will determine the results of the quality of our education.

According to Rusman (2016:202), cooperative learning is a form of learning in which students learn and work in small groups collaboratively whose members consist of four to six people with heterogeneous group structures. This cooperative learning model makes students more active when the teaching and learning process takes place.

In this study, the researchers focused more on the cooperative learning model because it can activate the learning process in the classroom. Students must be more active in this learning, while the teacher acts more as a facilitator. According to Nurulhayati (2002 in Rusman 2016:203), cooperative learning is a learning strategy that involves student participation in small groups to interact with each other.

The researchers conducted preliminary research as concrete evidence on the problem in this study. The researcher gave questionnaires to students of 2016, 2017 and 2018 PBJ study programs who have studied and are also studying Nichijo Hyogen. In this survey, 40 students were willing to fill out the researchers' questionnaire in 2016, 2017 and 2018 batches. This survey found that because Hyogen's lessons are considered difficult. Learning is needed to inspire students to be more active and think critically. One cooperative learning model that inspires students to think critically and actively is the 'tea party' cooperative learning model. An example of a case experienced by researchers, in Nichijo Hyogen's learning, the researchers still found it difficult to understand the material presented by the teacher.

Problems often faced by researchers are learning that does not inspire critical and active thinking, often learning focuses on the teacher or student who leads the course of the lecture or presentation, and also in learning, it requires attraction so that students are more enthusiastic in learning

Therefore, the researchers wanted to apply the 'tea party' cooperative learning model to the third-grade students of the Japanese language Education Department Universitas Muhammadiyah Yogyakarta in the Nichijo Hyogen course 
and find out the students' responses to the 'tea party' cooperative learning.

\section{RESEARCH METHOD}

The method used in this study was a descriptive method with a qualitative research approach. According to Sugiyono (2016:13-14), qualitative research methods can be interpreted as research methods based on the philosophy of postpositivism, used to examine the condition of natural objects (as opposed to experiments) where the researcher is the key instrument, data collection techniques are carried out by triangulation (combined), data analysis is inductive/qualitative, and qualitative research results emphasize meaning rather than generation. For Data Collection by observation. The data sources of this study were 48 students consisting of class A and B of the Japanese Language Education Study Program, Universitas Muhammadiyah Yogyakarta from level III in 2020/2021 in the Nichijo Hyougen course.

The aspect researched was Japanese language learning before using the 'tea party' cooperative learning model, its application, and student responses. This study used the data analysis technique proposed by Miles \& Huberman, where the researcher observes the ongoing activities, then summarizes the data and presents narrative data, Sugiyono, (2015). I Analyse Data observation by reduction data, atagorize and in the ens Anylize.

\section{FINDINGS AND DISCUSSIONS}

Based on the data analysis obtained through observation, the flow of Japanese language learning with the 'tea party' cooperative learning model is as follows:

a. The first stage is when the lecturer provides an overview and explains the 'tea party' cooperative learning model. The lecturer asks students first to study the material used in the next class, both students who take online lectures and students who take face-to-face lectures.

b. The second stage is the core activity using a 'tea party' cooperative learning model. Before starting, the teacher forms pairs of online classes and face-to-face classes combined or called blended learning.

c. The third stage is evaluation and closing. After the learning material using the 'tea party' cooperative learning model is complete, the lecturer evaluates the material and learning by the direct question and answers with students who take online classes and students who take part in face-to-face lectures, and lecturers provide feedback to students the lecture was closed.

Based on the questionnaire results distributed to students, three aspects are noted by the researchers who conducted interviews with the lecturer of the Nichijo Hyougen course showing the following information.
1. Nichijo Hyougen's learning

a. More than $50 \%$ of Nichijo Hyougen's learning activities at PBJ UMY before using the 'Tea Party' Learning Model felt good.

b. More than the average learning model used in Japanese, especially in the Nichijo Hyougen course, was always varied (not boring).

c. More than half of the students were always enthusiastic about participating in Nichijo Hyougen's learning using any learning model used by the lecturer.

2. Application of the 'tea party' learning model

a. 74\% of students enjoyed learning in groups (Cooperative).

b. $55 \%$ of students felt that learning became more practical with the 'tea party' learning model.

c. $86 \%$ of students feel that learning with the 'tea party' learning model can improve teamwork.

3. Benefits of the 'tea party' learning model

a. $78 \%$ of students learning with the 'tea party' learning model could help improve learning skills in the classroom and online.

b. $76 \%$ of students felt that the learning steps in the Tea Party learning model are easy to implement.

c. $76 \%$ of students felt more active when the 'tea party' learning model was applied in the classroom or online

After being applied to the Nichijo Hyogen course, this' tea party' learning model had a good effect, as shown by the results of point 7 interviews that previously students tended to be passive in learning. With this model, the students became more active and independent in seeking learning information.

\section{CONCLUSION}

Based on the results conducted on the application of the 'tea party' cooperative learning model in the Nichijo Hyougen course for the 2020-2021 academic year, the researchers drew the following conclusions.

First, the application of the 'tea party' cooperative learning model in the Nichijo Hyogen course to students of the Japanese Language Education study program at Universitas Muhammadiyah Yogyakarta in the third semester in semester 5 .

a. The first stage was for the lecturer to provide an overview and explain the 'tea party' cooperative learning model, combined with blended learning.

b. The second stage was the core activity using a 'tea party' cooperative learning model, combined with blended learning.

c. The third stage was evaluation and closing. After the learning material using the 'tea party' cooperative learning model was complete, the lecturer evaluated the material and learning by a direct question and answered with students combined with blended learning. Lecturers then provided feedback to students. After that, the lecture was closed. 
Second, the Japanese Language Education study program students at Universitas Muhammadiyah Yogyakarta in the third semester in the 5th semester agreed to the 'tea party' cooperative learning model 1 in the Nichijo Hyogen course. The students could express opinions when talking to other friends, seen from $88 \%$ from the result. Students also felt that they could foster competition in learning as indicated by the answer choices agreeing that students claimed that their learning ability increased.

\section{REFERENCES}

[1] Achmad, Mahmud. 2008. Tehnik Simulasi dan Permodelan. Yogyakarta: Universitas Gajah Mada.

[2] Al-Tabany, Trianto Ibnu Badar. 2014. Mendesain Model Pembelajaran Inovatif, Progresif dan Kontekstual. Jakarta: Prenadamedia Group.

[3] Andri Wicaksono, dkk. (2015). Teori Pembelajaran Bahasa (Suatu Catatan Singkat). Yogyakarta: Garudawacha.

[4] Arends, Richard I. 2013. Belajar untuk Mengajar, Learning to Teach. Jakarta: Salemba Humanika.

[5] Aulidha, M. 2019. Penerapan Group Investigation (GI) dalam Pembelajaran Bahasa Jepang Tingkat SMA.

[6] Bugin, B. 2010. Metode Penelitian Kualitatif. Jakarta: Rajawali Pers.

[7] Cayaray, S. 2014. Model layanan perpustakaan sekolah luar biasa. Bandung: Universitas Pendidikan Indonesia

[8] Chomaidi, \& Salamah. 2018. Pendidikan dan Pengajaran. Jakarta: PT Grasindo.

[9] Fathurroman, M. 2016. Model-model Pembelajaran Inovatif. Jogjakarta: Ar-Ruzz Media.

[10] Khamidiyah, Izzah Riyatna. (2018). Penerapan Cooperative Learning Tipe Tea Party Untuk Meningkatkan Keterampilan MenemukanIde Pokok Paragraf Pada Mata Pelajaran Bahasa indonesia Di Kelas Iv Mi Bina Bangsa Krembangan Surabaya. Surabaya: Universitas Islam Negeri Sunan Ampel Surabaya

[11] Meisa dan Indraswari. 2017. Belief Pembelajar Bahasa Jepang terhadap Student Centered Learning (SCL) dalam Perkuliahan Chujokyu Dokkai. Yogyakarata: Universitas Muhammadiyah Yogyakarta.

[12] Mista. 2018. Penerapan Model Pembelajaran Tipe Tea Party untuk Meningkatkan Motivasi Belajar Siswa pada Mata Pelajaran Ilmu Pengetahuan Alam di Kelas V Madrasah Ibtidayah Nurul Iman Kecamatan Kampar Tmur Kabupaten Kampar. UIN Suska Riau Repository.

[13] Munir. (2009). Pembelajaran jarak jauh berbasis teknologi informasi dan komunikasi. Bandung: Penerbit Alfabeta

[14] Nurdyansyah dan Fahyuni. 2016. Inovasi Model Pembelajaran Sesuai Kurikulum 2013. Sidoarjo: Nizamia Learning Center

[15] Pebriani, S. H. 2016. Penerapan Model Pembelajaran Kooperatif Tipe Tea Party untuk Meningkatkan Penguasaan Kosakata Bahasa Jepang. Repository Indonesia University of Education.

[16] Pranoto, Alvini.dkk. 2009. Sains dan Teknologi. Jakarta: PT Gramedia Pustaka Utama.

[17] Prayogi, G. G. 2017. Penggunaan Media Komik Nihonjin No Shiranai Nihongo dalam Pembelajaran Chuukyuu Dokkai.

[18] Riskayanti, W. K. 2019. Keefektifan Model Pembelajaran Kooperatif Tipe Tea Party dalam Keterampilan Berbicara Bahasa Jerman. Eralingua.

[19] Rofifah, Khairunnisa. 2016. Formulasi Permasalahan Terhadap Penggunaan E-Learning Share Its Berdasarkan Policy Analysis Of Multiactor Systems. Institut Teknologi Sepuluh Nopember.
[20] Rusman. 2011. Model-model Pembelajaran . Jakarta: PT. Grafindo Persada.

[21] S. Chomaidi. Pendidikan Dan Pengajaran Strategi Pembelajaran Sekolah, PT. Grasindo, 2018.

[22] Setiawan, P. (2020). Pengertian E-learning Pengertian Elearning Menurut Para Ahli Karakteristik E-learning Manfaat Elearning.

[23] Sherman, W Lawrence. (1996). Cooperative Learning In Post Secondary Education: Implications From Social Psychology For Active Learning Experiences. Ohio: Miami University

[24] Sudarman. 2014. Pengaruh Strategi Pembelajaran Blended Learning Terhadap Perolehan Belajar Konsep dan Prosedur Pada Mahasiswa yang Memiliki Self-Regulated Learning Berbeda. Jurnal Pendidikan dan Pembelajaran, Vol. 21, 01, April.

[25] Sugiyono. 2016. Metode Penelitian Kombinasi (Mixed Methods). Bandung: Alfabeta.

[26] Surya. Mohamad. 1985. Psikologi Pendidikan. Bandung: Pembangunan Jaya.

[27] Sutedi, D. 2009. Penelitian Pendidikan Bahasa Jepang (Panduan bagi Guru dan Calon Guru dalam Meneliti Bahasa Jepang dan Pengajarannya). Bandung: Humaniora.

[28] Tyas. 2014. Peningkatan Kemampuan Kognitif Melalui Penerapan Model Discovery Learning Pada Anak Kelompok B PAUD Pintar Tuliskriyo Kabupaten Blitar. Malang: Universitas Negeri Malang.

[29] Warsono dan Hariyanto. (2017). Pembelajaran Aktif: Teori dan Asesmen. Bandung: PT Remaja Rosdakarya. 